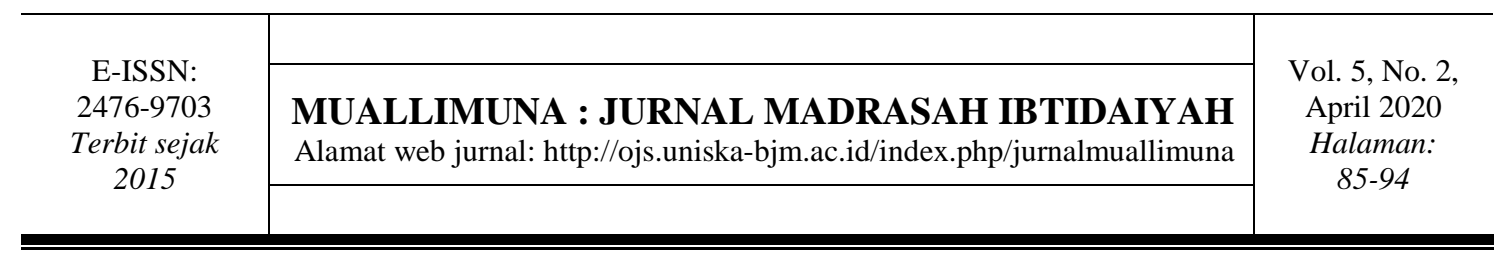

\title{
KEMAMPUAN BERPIKIR KREATIF MATEMATIS SISWA MELALUI PENGGUNAAN STRATEGI MATHEMATICAL BET LINE
}

\author{
Sandi Amirulloh ${ }^{1}$, H. Yayan Carlian ${ }^{2}$, Siti Khozanatu Rohmah ${ }^{3}$ \\ 1,2,3 PGMI, Universitas Islam Negeri Sunan Gunung Djati Bandung \\ ${ }^{1}$ sandiamirulloh46@gmail.com
}

\begin{abstract}
Abstrak: Penelitian ini beranjak dari masalah yang dikemukakan oleh hasil survey Trends International Mathematic Science Study (TIMSS). Hasil survei tersebut menunjukkan bahwa hanya $2 \%$ siswa di Indonesia yang mampu mengerjakan soal-soal cerita matematika. Hal tersebut disebabkan oleh karena kemampuan berpikir kreatif matematis siswa tergolong rendah. Tujuan dari penelitian ini adalah untuk mengetahui peningkatan kemampuan berpikir kreatif matematis siswa yang mengikuti pembelajaran dengan strategi mathematical bet line lebih baik secara signifikan dari siswa yang mengikuti pembelajaran dengan model konvensional. Penelitian ini merupakan penelitian quasi eksperimen dengan desain yang digunakan yaitu nonequivalent control group design. Sampel dalam penelitian ini adalah seluruh siswa kelas IV di salah satu Madrasah Ibtidaiyah di Kecamatan Rancaekek Kabupaten Bandung. Instrumen yang digunakan dalam penelitian ini adalah tes yang sesuai dengan indikator kemampuan berpikir kreatif matematis. Hasil penelitian menunjukkan bahwa peningkatan kemampuan berpikir kreatif matematis siswa yang mengikuti pembelajaran dengan strategi mathematical bet line lebih baik dari siswa yang mengikuti pembelajaran dengan model konvensional.
\end{abstract}

Kata Kunci: Strategi Mathematical Bet Line, Kemampuan Berpikir Kreatif Matematis

\section{ABILITY OF MATH CREATIVE THINKING THROUGH THE USE OF THE MATHEMATICAL BET LINE STRATEGY}

\begin{abstract}
This research moved from the problem raised by the Trends International Mathematics Science Study (TIMSS) survey. The survey results show that only 2\% of students in Indonesia can work on math story problems. It is caused by the students' mathematical creative thinking ability is relatively low. The purpose of this study is to know of increasing mathematical creative thinking ability of students who take learning with mathematical bet line strategies significantly better than students who take learning with conventional models. This research is a quasi-experimental study with the design used is a nonequivalent control group design. The sample in this study were all fourthgrade students in one of the Madrasah Ibtidaiyah in Rancaekek District, Bandung Regency. The instrument used in this study is a test that fits the mathematical creative thinking ability indicator. The results showed that increasing mathematical creative thinking ability of students who took learning with mathematical bet line strategies was better than students who followed learning with conventional models.
\end{abstract}

Keywords: Mathematical Bet Line Strategy, Mathematical Creative Thinking Ability 


\section{PENDAHULUAN}

Pembelajaran matematika menurut Ruseffendi (Heruman, 2008) yaitu suatu ilmu yang dipelajari dan tidak lepas dari simbol-simbol dan angka serta ilmu yang tidak bisa diterima pembuktiannya secara induktf. Pembelajaran matematika juga dapat mengembangkan kreativitas berpikir siswa, sehingga siswa memiliki pola yang teratur dan terstruktur serta mampu menguasai materi matematika dengan baik.

Tujuan pembelajaran matematika untuk siswa tingkat SD/MI tercantum dalam Depdiknas (2001) yaitu, siswa paham terhadap konsep matematika, mampu membuat keterkaitan antarkonsep dan menerapkan perhitungan matematika, serta 1) Menerapkan cara berpikir logis, kritis dan kreatif dalam menjelaskan konsep matematika. 2) Siswa mampu melakukan problem solving. 3) Mengkomunikasikan buah pikiran melalui representasi seperti simbol, tabel, diagram, atau perantara lain untuk memamahi segala kondisi yang ada. 4) Menumbuhkan rasa menghargai fungsi dari matematika.

Pembelajaran matematika di MI dapat membuat kemampuan siswa menjadi berkembang dalam berpikir logis, kritis, kreatif maupun sistematis. Menurut Wahyudi dan Inawati (Putri, 2017) matematika dapat berguna untuk membantu manusia memahami permasalahan disekitarnya. Matematika dapat dikatakan sebagai pengetahuan yang berhubungan dengan segala bentuk prosedur sistematis untuk digunakan dalam menyelesaikan permasalahan perhitungan. Namun dari banyaknya mata pelajaran di tingkat SD/MI, matematika dipandang sebagai pelajaran yang tidak disukai siswa-siswa. Siswa berpandangan bahwa matematika itu sangat sulit dan membosankan untuk dipelajari. Padahal matematika adalah pelajaran yang akan dipergunakan dan seluruh siswa harus mempelajarinya mulai dari pendidikan tingkat dasar sampai tingkat yang lebih tinggi. Dengan diajarkannya matematika kepada seluruh siswa, siswa mencapai berbagai kemampuan berpikir diantaranya yaitu kemampuan berpikir kreatif matematis.

Kemampuan berpikir kreatif matematis adalah kemampuan yang digunakan untuk menyelesaikan masalah matematika secara kreatif, membangun pemikiran yang terstruktur, dan mampu menyatakan ide-ide yang berbeda dari yang diajukan orang lain (Sani, 2019). Adapun indikator kemampuan berpikir kreatif matematis menurut Torrance (Lestari, 2017), yaitu: 1) Kelancaran (fluency), yaitu memberikan penjelasan dalam menjawab soal; 2) Keluwesan (flexibility), yaitu memberikan jawaban atau ide dengan banyak cara; 3) Keaslian (originality), yaitu memberikan jawaban atau ide baru dalam menyelesaikan masalah; 4) Elaborasi (elaboration), yaitu memberikan jawaban atau ide dan mampu mengembangkan masalah tersebut.

Namun berdasarkan hasil survey lembaga Trend International Mathematics and Science Study (TIMMS) terdapat pada kemampuan tersebut. bahwa kemampuan berpikir kreatif matematis siswa berada pada tingkat golongan rendah, karena hanya $2 \%$ siswa di Indonesia yang mampu mengerjakan soal-soal yang berkategori high dan advance itu semua karena dibutuhkannya kemampuan berpikir kreatif dalam menyelesaikan masalah yang ada pada matematika (Ismara \& Suratman, 2016). Lembaga Trend International Mathematics and Science Study (TIMMS) juga menyebutkan Indonesia menduduki rangking ke-28 dari 50 negara tingkat internasional pada materi geometri (Pusat Penilaian Pendidikan Badan Penelitian dan Pengembangan, 2016). Adapun hasil uji coba soal yang dilakukan dengan pokok bahasan bangun datar segitiga diperoleh hasil bahwa kemampuan berpikir kreatif matematis di MI AT-TAQWA Rancaekek masih kurang. Dilihat dari hasil rata-rata yaitu 21,86 dan hanya 1 siswa yang nilainya mencapai KKM yang ditentukan. 
Jika hal tersebut tidak diatasi dengan pelatihan, kemampuan berpikir kreatif siswa tidak akan meningkat dan akan membuat sekolah-sekolah menghasilkan lulusan yang kurang kreatif dalam berpikir (Noer, 2009). Sedangkan jika hal tersebut dibiarkan, maka dikhawatirkan Negara kita akan tertinggal jauh oleh Negara lain, mengingat matematika mendasari sains dan teknologi (Hendi, 2013).

Peningkatan kemampuan berpikir kreatif matematis tidak dapat dicapai oleh siswa apabila pembelajaran hanya berorientasi pada masalah prosedural dan rutin. Guru hendaknya menerapkan pendekatan, strategi, dan model pembelajaran yang membuat siswa terlibat dalam pembelajaran baik secara mental, fisik, maupun sosial sehingga kemampuan siswa dapat berkembang dan tujuan pembelajaran yang telah direncanakan dapat tercapai.

Salah satu alternatif strategi pembelajaran yang dapat diterapkan adalah pembelajaran diskursus. penggunaan strategi mathematical bet line. Strategi mathematical bet lline ini merupakan strategi yang di rancang untuk menjadikan pembelajaran diskursus dan mendukung sense making siswa ketika guru mengajarkan pelajaran matematika yang berkaitan dengan masalah cerita. Dalam pembelajaran literasi, strategi mathematical bet line digunakan sebagai pendekatan interaktif dan berkelanjutan untuk melibatkan siswa dengan teks bermakna. Secara khusus, bet line menawarkan kesempatan bagi siswa untuk melihat bagaimana pembaca berpikir dan mulai memantau pemahaman mereka (Pratiwi, dkk., 2019)

Adapun tujuan dari strategi mathematical bet line yaitu membantu siswa-siswa dalam menyelesaikan masalah cerita matematika dengan cara membuat sebuah prediksi yang ditaruhkannya dan tanggap terhadap prediksi yang dilontarkan oleh yang lain mengenai kejadian yang akan terjadi pada masalah yang dipaparkan oleh guru. Sedangkan dalam proses pembelajarannya strategi ini memunculkan interaksi antara guru dan siswa yang dimulai dengan guru membuka sebuah permasalahan dalam membuat soal cerita matematika yang belum rampung dan berhenti ketika siswa mulai dapat memprediksi lanjutan dari masalah yang akan muncul dan mempertaruhkan pendapatnya, sehingga siswa dituntut untuk dapat meningkatkan berpikir kreatifnya dengan hal tersebut (Pratiwi, dkk., 2018)

Berikut tips dalam menerapkan mathematical bet line (Lara Dick, 2016), yaitu: 1) Siapkan permasalahan dalam bentuk tulisan. Bisa gunakan whiteboard, in focus, dan lain-lain agar siswa dapat mendiskusikannya. 2) Pilih permasalahan sesuai dengan keinginan siswa atau guru dapat memilihnya sendiri yang disesuaikan dengan karakter siswa. 3) Dalam mathematical bet line semua prediksi tidak ada yang benar dan salah meskipun prediksi yang dibuat tidak berkaitan dengan mathematical sense. Biarkan siswa untuk membuat prediksi dan membuktikan prediksinya. 4) Dalam mathematical bet line guru juga harus dapat membangun daya pikir siswa melalui pertanyaan yang mendukung seperti contoh berikut ini: a) Apa saja permasalahan yang diketahui? Apa yang akan kamu lakukan dalam mengatasi masalah tersebut. b) Apa alasanmu berpikir seperti itu? c) Jika prediksimu tepat, bagaimana pertanyaan atas permasalahan tersebut? Ketika mengajukan pertanyaan prediksi disarankan memilih dua atau tiga siswa agar pembelajaran efektif. Namun, guru dapat memberi kesempatan pada siswa lain untuk menanggapi prediksi temannya.

Menurut Merce menyatakan bahwa strategi ini dapat mengembangkan pemikir yang lebih kreatif dan mandiri sekaligus memperkuat pengetahuan prosedural, dapat mendukung siswa dalam komunikasi matematika baik tertulis maupun lisan, karena mereka membangun pemahaman matematika baru, sehingga siswa lebih aktif, serta 
menjadikan siswa belajar menemukan ide melalui pengalaman belajar baik dari diri sendiri maupun dari lingkungan kelas (Pratiwi, 2017).

\section{METODE}

Penelitian ini dilaksanakan di MI AT-TAQWA Rancaekek, pada kelas IV yang berlokasi di Kecamatan Rancaekek. Populasi dari penelitian ini yaitu siswa kelas IV MI ATTAQWA Rancaekek. Sampel dari penelitian merupakan seluruh siswa kelas IV yang berjumlah 44 siswa. Peneliti mengelompokkan sampel penelitian ke dalam dua kelompok, yaitu kelompok eksperimen 22 siswa dan kelompok kontrol 22 siswa. Adapun pemilihan kelompok sampel penelitian dilakukan secara purposive dan tidak dilakukan random. Sehingga tidak dilakukan pengelompokkan secara acak. Pendekatan yang digunakan adalah pendekatan kuantitatif dengan metode quasi eksperimen dengan desain Nonequivalent Control Group Design.

\section{Kelas Eksperimen \\ Kelas Kontrol}

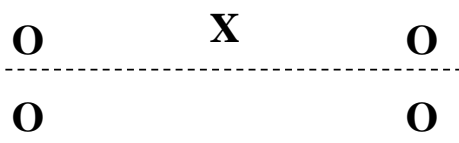

Keterangan:

$\mathrm{X} \quad$ :Treatment kepada kelas eksperimen menggunakan strategi mathematical bet line

$\mathrm{O} \quad$ : Pretest/Posttest berpikir kreatif kelas eksperimen/kontrol

: Subjek tidak dikelompokkan secara random

Prosedur penelitian terdiri dari tiga tahap yaitu, tahap persiapan, tahap pelaksanaan, dan tahap analisis data. Pada tahap persiapan dimulai dengan mengidentifikasi masalah penelitian, melakukan kajian literatur, membuat hipotesis penelitian, menyususn langkah-langkah dalam mengimplementasikan tindakan, serta memilih subjek penelitian yang terdiri dari kelas eksperimen dan kelas kontrol. Pada tahap ini juga dilakukan penyusunan instrumen penelitian, pengujian instrumen, dan perbaikan instrumen, sehingga pada tahap ini diperoleh instrumen penelitian yang siap dan layak pakai. Tahap kedua diawali dengan memberikan pre test pada kedua kelas untuk mengetahui kemampuan awal berpikir kreatif siswa. Setelah dilakukan pre test, dilanjutkan dengan melaksanakan pembelajaran pada kelompok eksperimen yaitu dengan menerapkan pembelajaran dengan strategi mathematical bet line dan pembelajaran dengan model konvensional pada kelas kontrol. Setelah seluruh kegiatan pembelajaran selesai kemudian dilakukan post test pada kedua kelas. Tahap analisis data dilakukan dengan pengolahan dan analisis data penelitian serta penulisan hasil penelitian. Analisis data yang digunakan adalah uji perbedaan dua rata-rata dengan memperhatikan normalitas dan homogenitas.

Instrumen yang digunakan dalam penelitian ini yaitu tes. Tes ini digunakan untuk mengukur kemampuan berpikir kreatif matematis. Tes kemampuan berpikir kreatif matematis berbentuk uraian yang disusun oleh peneliti sesuai dengan indikatorindikatornya. 


\section{HASIL DAN PEMBAHASAN}

\section{Hasil}

Hasil penelitian ini didapatkan berdasarkan analisis data yang terdiri dari data kuantitatif. Data kuantitatif diperoleh berdasarkan tes kemampuan berpikir kreatif matematis pokok bahasan bangun datar segitiga, yaitu pre test dan post test serta $\mathrm{N}$-gain. Data yang terkumpul diambil dari siswa yang terdiri dari dua kelas. Tujuannya untuk mendiskripsikanpeningkatan kemampuan berpikir kreatif matematis siswa yang mengikuti pembelajaran dengan strategi mathematical bet line lebih baik dari siswa yang mengikuti pembelajaran dengan model konvensional. Berikut adalah skor statistiik deskriptif pre test dan post test serta $\mathrm{N}$-gain di kelas eksperimen dan kelas kontrol:

Tabel 1. Statistik Deskriptif Kemampuan Berpikir Kreatif Matematis

\begin{tabular}{lllllllll}
\hline & \multicolumn{3}{l}{ Kelas Eksperimen } & \multicolumn{5}{c}{ Kelas Kontrol } \\
\hline & N & Min. & Max. & Rata-rata & N & Min. & Max. & Rata-rata \\
\hline Pre test & 22 & 6 & 38 & 19,32 & 22 & 6 & 31 & 13,07 \\
\hline Post test & 22 & 44 & 81 & 53,69 & 22 & 25 & 75 & 43,18 \\
\hline N-Gain & 22 & 0,20 & 0,73 & 0,42 & 22 & 0,18 & 0,64 & 0,34 \\
\hline
\end{tabular}

a. Analisis Data Pre Test Kemampuan Berpikir Kreatif Matematis

1) Uji Normalitas

Sebelum dilakukan pembelajaran, peneliti melakukan pre test pada kedua kelas tersebut. kemudian dilakukan analisis data untuk mengetahui apakah kemampuan awal berpikir kreatif matematis siswa sama atau berbeda secara signifikan. Setelah diperoleh hasil pretest dari kedua kelas, maka yang pertama dilakukan adalah uji normalitas.

Tabel 2. Uji Normalitas Hasil Pre Test Kemampuan Berpikir Kreatif Matematis

\begin{tabular}{cccccc}
\hline Kelas & \multicolumn{3}{c}{ One-Sample Kolmogorov- } & Kesimpulan & Makna \\
& $\mathrm{N}$ & $\begin{array}{c}\text { Kolmogorov- } \\
\text { Smirnov Z }\end{array}$ & $\begin{array}{c}\text { Sig. }(2 \\
\text { pihak) }\end{array}$ & & \\
\hline Eksperimen & 22 & 0,757 & 0,615 & $\mathrm{H}_{0}$ diterima & Berdistribusi normal \\
\hline Kontrol & 22 & 1,436 & 0,032 & $\mathrm{H}_{0}$ ditolak & Berdistribusi tidak normal \\
\hline
\end{tabular}

Berdasarkan tabel di atas menunjukkan bahwa di kelas eksperimen memiliki nilai signifikansi 0,615 dan kelas kontrol memiliki signifikansi 0,032. Pada kelas eksperimen signifikansi lebih besar dari $\alpha=0,05$ sehingga $\mathrm{H}_{0}$ diterima. Namun, pada kelas kontrol signifikansi lebih kurang dari $\alpha=0,05$ sehingga $\mathrm{H}_{0}$ ditolak .Dengan demikian, hasil pretest kemampuan berpikir kreatif matematis pada kelas eksperimen berdistribusi normal dan kelas kontrol berdistribusi tidak normal.

2) Uji Man Whitney

Setelah diketahui hasil pre test kemampuan berpikir kreatif matematis pada kelas eksperimen berdistribusi normal dan kelas kontrol berdistribusi tidak normal, maka selanjutnya dilakukan uji man whiteney. Uji man whiteney dilakukan Jika salah satu atau keduanya tidak normal, maka digunakan perhitungan dengan statistik non parametik.

Tabel 3. Uji Man Whitney Hasil Pre Test Kemampuan Berpikir Kreatif Matematis

\begin{tabular}{cccc}
\hline Mean1 & Mean2 & Sig. & Kesimpulan \\
\hline 27,14 & 17,86 & 0,014 & $\mathrm{H}_{0}$ ditolak \\
\hline
\end{tabular}


Berdasarkan tabel di atas diperoleh hasil menunjukkan nilai signifikansi sebesar 0,014 . Nilai tersebut lebih kecil daripada nilai $\alpha$ yang dipilih, yaitu $\alpha=0,05$. Dengan demikian dapat disimpulkan, terdapat perbedaan secara signifikan kemampuan awal berpikir kreatif matematis siswa di kelas eksperimen dan di kelas kontrol.

\section{b. Analisis Data Post Test Kemampuan Berpikir Kreatif Matematis}

1) Uji Normalitas

Setelah itu dilakukan pembelajaran pada kedua kelas tersebut, di kelas eksperimen pembelajaran dengan strategi mathematical bet line dan di kelas kontrol pembelajaran denga model konvensional. Kemudian dilakukan post test, kemudian stelah hasil post test didapatkan di kedua kelas, maka yang pertama dilakukan adalah uji normalitas.

Tabel 4. Uji Normalitas Hasil Post Test Kemampuan Berpikir Kreatif Matematis

\begin{tabular}{cccccc}
\hline Kelas & \multicolumn{3}{c}{ One-Sample Kolmogorov- } & Kesimpulan & Makna \\
Smirnov & $\mathrm{N}$ & $\begin{array}{c}\text { Kolmogorov- } \\
\text { Smirnov Z }\end{array}$ & $\begin{array}{c}\text { Sig. }(2 \\
\text { pihak) }\end{array}$ & & \\
\hline Eksperimen & 22 & 1,264 & 0,082 & $\mathrm{H}_{0}$ diterima & Berdistribusi normal \\
\hline Kontrol & 22 & 0,972 & 0,301 & $\mathrm{H}_{0}$ diterima & Berdistribusi normal \\
\hline
\end{tabular}

Berdasarkan tabel di atas menunjukkan bahwa di kelas eksperimen memiliki nilai signifikansi 0,082 dan kelas kontrol memiliki signifikansi 0,301. Pada kelas eksperimen dan kelas kontrol signifikansi lebih besar dari $\alpha=0,05$ sehingga $\mathrm{H}_{0}$ diterima. Dengan demikian, hasil post test kemampuan berpikir kreatif matematis pada kelas eksperimen dan kelas kontrol berdistribusi normal.

2) Uji Homogenitas

Setelah memperoleh hasil post test kemampuan berpikir kreatif matematis pada kelas eksperimen dan kelas kontrol yang berdistribusi normal, maka selanjutnya dilakukan uji homogenitas. Uji homogenitas dilakukan untuk mengetahui apakah variansi data dari kelas eksperimen dan kelas kontrol yang dianalisis homogen atau tidak. Uji homgenitas dilakukan dengan Levene's test dengan taraf signifikansi $\alpha=0,05$.

Tabel 5. Uji Homogenitas Hasil Post Test Kemampuan Berpikir Kreatif Matematis

\begin{tabular}{ccccc}
\hline Levene Statistic & Dk1 & Dk2 & Sig. & Kesimpulan \\
\hline 0,160 & 1 & 42 & 0,691 & $\mathrm{H}_{0}$ diterima \\
\hline
\end{tabular}

Berdasarkan tabel di atas diperoleh nilai P-Value sebesar 0,691. Nilai tersebut lebih besar daripada nilai $\alpha$ yang dipilih, yaitu $\alpha=0,05$, sehingga $\mathrm{H}_{0}$ diterima. Dengan demikian, hasil post test kemampuan berpikir kreatif matematis pada kelas eksperimen dan kelas kontrol adalah homogen.

3) Uji Perbedaan Rata-rata

Setelah memperoleh hasil post test kemampuan berpikir kreatif matematis pada kelas eksperimen dan kelas kontrol yang berdistribusi normal dan homogen, maka selanjutnya dilakukan uji t atau uji independent $t$-test. 
Tabel 6. Uji Perbedaan Rata-rata Hasil Post Test

Kemampuan Berpikir Kreatif Matematis

\begin{tabular}{cccc}
\hline $\mathrm{T}$ & $\mathrm{Dk}$ & Sig. (2 pihak) & Kesimpulan \\
\hline 2,221 & 42 & 0,032 & $\mathrm{H}_{0}$ ditolak \\
\hline
\end{tabular}

Berdasarkan tabel di atas hasil yang diperoleh menunjukkan nilai signifikansi (2 Pihak) sebesar 0,032. Nilai tersebut lebih kecil daripada nilai $\alpha$ yang dipilih yaitu $\alpha=0,05$, sehingga $\mathrm{H}_{0}$ ditolak. Dengan demikian dapat disimpulkan, terdapat perbedaan secara signifikan kemampuan berpikir kreatif matematis siswa yang mengikuti pembelajaran dengan strategi mathematical bet line dengan siswa yang mengikuti pembelajaran dengan model konvensional.

\section{c. Analisis Data N-Gain Kemampuan Berpikir Kreatif Matematis}

1) Uji Normalitas

Selanjutnya untuk mengetahui peningkatan kemampuan berpikir kreatif berdasarkan skor N-Gain dilakukan di kelas eksprimen dan kelas kontrol. , maka yang pertama dilakukan adalah uji normalitas.

Tabel 7. Uji Normalitas Hasil N-Gain Kemampuan Berpikir Kreatif Matematis

\begin{tabular}{cccccc}
\hline Kelas & \multicolumn{3}{c}{$\begin{array}{c}\text { One-Sample Kolmogorov- } \\
\text { Smirnov }\end{array}$} & Kesimpulan & Makna \\
\hline N & $\begin{array}{c}\text { Kolmogorov- } \\
\text { Smirnov Z }\end{array}$ & $\begin{array}{c}\text { Sig. }(2 \\
\text { pihak) }\end{array}$ & & \\
\hline Eksperimen & 22 & 0,778 & 0,580 & $\mathrm{H}_{0}$ diterima & Berdistribusi normal \\
\hline Kontrol & 22 & 0,775 & 0,586 & $\mathrm{H}_{0}$ diterima & Berdistribusi normal \\
\hline
\end{tabular}

Berdasarkan tabel di atas menunjukkan bahwa di kelas eksperimen memiliki nilai signifikansi 0,580 dan kelas kontrol memiliki signifikansi 0,586. Pada kelas eksperimen dan kelas kontrol signifikansi lebih besar dari $\alpha=0,05$ sehingga $\mathrm{H}_{0}$ diterima. Dengan demikian, hasil N-Gain kemampuan berpikir kreatif matematis pada kelas eksperimen dan kelas kontrol berdistribusi normal.

2) Uji Homogenitas

Setelah memperoleh hasil posttest kemampuan berpikir kreatif matematis pada kelas eksperimen dan kelas kontrol yang berdistribusi normal, maka selanjutnya dilakukan uji homogenitas. Uji homogenitas dilakukan untuk mengetahui apakah variansi data dari kelas eksperimen dan kelas kontrol yang dianalisis homogen atau tidak. Uji homgenitas dilakukan dengan Levene's test dengan taraf signifikansi $\alpha=0,05$.

Tabel 8. Uji Homogenitas Hasil N-Gain Kemampuan Berpikir Kreatif Matematis

\begin{tabular}{ccccc}
\hline Levene Statistic & Dk1 & Dk2 & Sig. & Kesimpulan \\
\hline 0,280 & 1 & 42 & 0,264 & $\mathrm{H}_{0}$ diterima \\
\hline
\end{tabular}

Berdasarkan tabel di atas diperoleh nilai P-Value sebesar 0,264. Nilai tersebut lebih besar daripada nilai $\alpha$ yang dipilih, yaitu $\alpha=0,05$, sehingga $\mathrm{H}_{0}$ diterima. Dengan demikian, hasil N-Gain kemampuan berpikir kreatif matematis pada kelas eksperimen dan kelas kontrol adalah homogen. 
3) Uji Perbedaan Rata-rata

Setelah memperoleh hasil posttest kemampuan berpikir kreatif matematis pada kelas eksperimen dan kelas kontrol yang berdistribusi normal dan homogen, maka selanjutnya dilakukan uji t atau uji independent $t$-test.

Tabel 9. Uji Perbedaan Rata-rata Hasil N-Gain Kemampuan Berpikir Kreatif Matematis

\begin{tabular}{cccc}
\hline $\mathrm{T}$ & $\mathrm{Dk}$ & Sig. (2 pihak) & Kesimpulan \\
\hline 2,130 & 42 & 0,039 & $\mathrm{H}_{0}$ ditolak \\
\hline
\end{tabular}

Berdasarkan tabel di atas hasil yang diperoleh menunjukkan nilai signifikansi (2 Pihak) sebesar 0,039 . Nilai tersebut lebih kecil daripada nilai $\alpha$ yang dipilih yaitu $\alpha=0,05$, sehingga $\mathrm{H}_{0}$ ditolak. Dengan demikian dapat disimpulkan, peningkatan kemampuan berpikir kreatif matematis siswa yang mengikuti pembelajaran dengan strategi mathematical bet line lebih baik secara signifikan dari siswa yang mengikuti pembelajaran dengan model konvensional.

\section{Pembahasan}

Berdasarkan hasil pengolahan dan analisis data, ditemukan adanya peningkatan kemampuan berpikir kreatif matematis siswa yang mengikuti pembelajaran dengan strategi mathematical bet line dan siswa yang mengikuti pembelajaran dengan model konvensioanal. Peningkatan berpikir kreatif matematis kelas eksperimen dibuktikan dengan $N$-gain yaitu 0,42 berada pada kriteria sedang. Sedangkan, pada kelas kontrol $N$ gainnya yaitu 0,34 berada pada kriteria sedang. Hasil pengujian statistik menunjukkan bahwa Peningkatan kemampuan berpikir kreatif matematis siswa MI kelas IV yang mengikuti pembelajaran dengan pembelajaran strategi mathematical bet line lebih baik secara signifikan dari siswa yang mengikuti pembelajaran dengan model konvensional. Hal ini dikarenakan dalam pembelajarannya di kelas eksperimen siswa dituntut untuk menemukan rumus luas dan keliling segitiga secara mandiri, serta penggunaannya dalam penyelesaian soal kemampuan berpikir kreatif matematis. Pertanyaan-pertanyaan untuk mengkonstruk pengetahuan siswa dituangkan dalam soal-soal yang dibuat sendiri oleh perserta didik dan harus dikerjakan.

Menurut Suherman (Muin, 2012) matematika tidak membenarkan nalar secara induktif, tapi mesti dengan pembenaran secara deduktif. Pembuktian deduktif yang dimaksud adalah dalam mengembangkan suatu pemikiran terdapat tahap-tahap permulaan yang membutuhkan bantuan contoh-contoh khusus. Proses bet atau bertaruh dilakukan dengan membuat soal dimulai dengan guru memberikan soal yang belum rampung, dan siswa harus mempertaruhkan ide atau pendapatnya hal apa yang akan terjadi selanjutnya. Sejalan dengan pendapat Association for the Advancement of Science (Crawford, 2001), proses pembelajaran yang terbaik adalah ketika siswa diberikan keleluasaan dalam menyatakan ide yang dimiliki. Pada kegiatan tersebut siswa dapat bertukar pemikiran dan leluasa menyampaikan argumen yang ia miliki secara kreatif. Selain itu, siswa juga dilatih untuk menerima pemikiran orang lain yang mungkin saja berbeda dengan pemikiran dirinya sendiri. Dengan menerima pemikiran orang lain, pengetahuan yang ia miliki menjadi bertambah dan semakin matang.

Kegiatan selanjutnya ketika siswa sudah membuat soal. Siswa harus mampu mengerjakan dan menjawab soal dengan benar dan mempresentasikannya didepan kelas, 
agar siswa mampu memahami terhadap masalah yang sudah dibuat semakin besar, serta pemikiran kreatif siswa semakin matang.

Kemudian pada pembelajaran secara berkelompok, aktivitas siswa yaitu mengisi lembar kegiatan peserta didik dengan cara mempertaruhkan argumennya dalam lingkup yang lebih kecil. Pada proses ini kerja sama siswa harus terjalin dengan erat. Kerja sama akan terjadi jika masing-masing anggota kelompok memiliki rasa percaya diri yang baik. Jika terdapat hal yang diragukan oleh salah satu aggota kelompok, siswa lain dapat membantu, sehingga menumbuhan keyakinan pada diri mereka terhadap konsep yang dipelajarinya. Pembelajaran dalam berkelompok berkaitan dengan teori kognitif sosial. Teori ini menyatakan bahwa proses berpikir manusia harus berfungsi sebagai poin inti analisis kepribadian dan pemikiran berkembang dalam konteks sosial yaitu seseorang mendapatkan pemikiran tentang diri dan dunianya melalui interaksi sosial (Pervin, 2012).

Berdasarkan pemaparan di atas, melalui pembelajaran dengan strategi mathematical bet line siswa mengalami peningkatan kemampuan berpikir kratif matematis pada pokok bahasan bangun datar segitiga lebih baik dari siswa yang mendapatkan pembelajaran konvensional.

\section{PENUTUP}

Pelaksanaan pembelajaran dengan strategi mathematical bet line membuat siswa menjadi terlibat secara aktif dalam proses pembelajaran melalui pertaruhan pendapat yang mereka lontarkan sehingga siswa dapat meingkakan kemampuan berpikir kreatif matematis. Dengan demikian, Peningkatan kemampuan berpikir kreatif matematis siswa MI kelas IV yang mengikuti pembelajaran dengan strategi mathematical bet line lebih baik secara signifikan dari siswa yang mengikuti pembelajaran dengan model konvensional.

\section{DAFTAR PUSTAKA}

Crawford, M. L. (2001). Teaching Contextually. Texas: CCI Publishing.

Hendi. (2013). Matematis Siswa Sma Negeri Di Wilayah Barat. Peningkatan Kemampuan Berpikir Kreatif Matematis Siswa Sma Negeri Di Wilayah Barat Kab. Subang Melalui Pembelajaran Dengan Pendekatan Saintifik, (2), 1-18.

Heruman. (2008). Model Pembelajaran Matematika Di Sekolah Dasar. Bandung: PT Remaja Rosdakarya.

Ismara, L., \& Suratman, D. (2016). Kemampuan Berpikir Kreatif Matematis Siswa dalam Menyelesaikan Soal Open Ended di SMP. Jurnal, 1-8.

Lara Dick, T. F. (2016). Supporting Sense Making With Mathematical Bet Lines. Teaching Children Mathematics.

Lestari, K. E. (2017). Penelitian Pendidikan Matematika. Bandung: PT Refika Aditama. Muin, A. \&. (2012). Strategi React Dalam Mengembangkan Kemampuan Berpikir Kreatif Matematis. Prosiding Seminar Nasional (P. 1). Bandung: Universitas Pasundan.

Noer, S. H. (2009). Hambatan Mengembangkan Kemampuan Berpikir Kreatif Matematis. Jurnal Universitas Kristen Satya Wacana, 2(1), 521-526.

Pervin, L. A. (2012). Psikologi kepribadian: Teori dan penialian disi kesembilan. Jakarta: Kencana.

Pratiwi, I. M. (2017). Strategi Mathematical Bet Line Terhadap Kemampuan Pemahaman Matematis Dan Self-Confidence Siswa Kelas IV.

Pratiwi, I. M., Herman, T., \& Jupri, A. (2018). Improvement of Mathematical Ability through Discourse Teaching with Mathematical Belt Line at the Fourth Grade of 
Elementary School. 7(1), 70-76. https://doi.org/10.23887/jpi-undiksha.v7i1.11722

Pratiwi, I. M., Rachman, S. P. D., \& Ariawan, V. A. N. (2019). Students' mathematical understanding reviewed by gender through discourse learning assisted by mathematical bet line strategy. Journal of Physics: Conference Series, 1157, 042103. https://doi.org/10.1088/1742-6596/1157/4/042103

Pusat Penilaian Pendidikan Badan Penelitian dan Pengembangan. (2016). Trends in International Mathematics and Science Study, Result From TIMSS 2015. Pusat Penilaian Pendidikan Badan Penelitian Dan Pengembangan, 1-2.

Putri, V. S. (2017). Pengaruh Penerapan Model Pisk Terhadap Kemampuan Pemecahan Masalah Matematika Bagi Siswa Kelas VIII SMP Negeri 2 Pringapus Kabupaten Semarang.

Sani, R. A. (2019). Pembelajaran Berbasis Hots (Higher Order Thinking Skills). Tangerang: Tira Smart. 